\title{
Iwona Bąk
}

Dr hab.

Zakład Statystyki, Katedra Zastosowań Matematyki w Ekonomii, Wydział Ekonomiczny, Zachodniopomorski Uniwersytet Technologiczny w Szczecinie iwona.bak@zut.edu.pl

\section{Beata Szczecińska}

Dr inż.

Katedra Analizy Systemowej i Finansów, Wydział Ekonomiczny, Zachodniopomorski Uniwersytet Technologiczny w Szczecinie beata.szczecinska@zut.edu.pl

DOI: $10.35117 / A \_E N G \_18 \_07 \_03$

\section{Expenditures of 50+ Households on transport and communications - statistical analysis}

Abstract: The dynamics and structure of consumption are influenced by demographic changes in the world. One of the most important is the phenomenon of aging society. The study covered households in Poland where the head of the household was at the age of 50 or more, according to the World Health Organization experts, they were people who had entered at least in the first year of presenile. The goal of this article is to analyse and model expenditure on transport and communication of these households. The analyses were carried out on the basis of a set of non-identifiable data of households budget which were bought from Central Statistical Office. Based on the estimated power-exponential model, it was found that the largest positive impact on transport and communications spending was the level of total expenditures per person. The diversification of the preferences of expenditure depending on the number of people in the family, the class of place of residence, socioeconomic group membership and the subjective assessment of the material situation of the households was also found important. In addition, it was found that the expenditures also depends on the characteristics of the household head: they decrease with age and the increase with level of education.

Keywords: 50+ Households; Econometric Model; Transport and Communication Expenditures

\section{Introduction}

The household is most often defined as a key unit in the sphere of consumption, the primary objective of which is to meet the individual and common consumption needs of the people composing it [9]. The level of consumption varies and depends on many determinants, among others: own subjective preferences, preferences, habits, and traditions, as well as existing objective limitations, such as household income and prices of goods and services. The demographic changes taking place in the world have a significant impact on the dynamics and structure of consumption. One of the most important is the aging of society, consisting in the increase in the number and share of the elderly population in the general population [4]. The aging of societies will translate not only into the sphere of social security but will affect virtually every sphere of life, from housing and market services to public transport or Internet portals [1]. These changes are important both for the creators of economic and social policy, as well as for producers and consumers because they allow determining how the size and structure of consumption will change over the next several years [7]. Analysis of elderly people's expenditure is an important issue from an economic point of view, because the 
population's expenditures are a kind of a photograph of consumer behavior on a macroeconomic scale, showing the focus on the purchase of specific groups of goods and services. They illustrate attachment to certain intake patterns that take shape over a longer period. The aging process of aging makes older people a desirable and valued group of consumers on the market.

Age is accepted as the main distinguishing feature of the seniors' segment. It is true that individual researchers are not fully in agreement as to the age at which a person is recognized as a senior. According to modern Anglo-Saxon physiologists, old age starts at the age of 50. German anthropologists count her from the age of 60, and the American proper age has been recognized only for 75 years [2]. Most often, however, it is assumed that the line separating the mature age from the older one runs at the level of 60 or 65 years. The article covers households in Poland, where the head of the household was aged 50 and over (in the further part of the work they will be referred to as 50+ households), i.e. according to the opinion of experts of the World Health Organization, those who have entered at least in age predetermined. 50-year-olds begin to experience many events (professional and family) that have a significant impact on their lifestyle and consumer behavior. Most people in this age group are at the peak of their careers, their children definitely leave the family home, and many of them have grandchildren. These changes involve many new experiences, which has an impact on the size and structure of their expenses [see 2].

The aim of the article is statistical analysis and modeling of expenditures on transport and communication. The survey concerned the year 2014, and the integrated data set included 20607 households in which the head of the farm was 50 years old and older. The analyzes were carried out on the basis of a set of unidentifiable unit data on household budgets, which were made available for a fee by the Central Statistical Office.

\section{General characteristics of expenditure on transport and communication in 50+ households}

In the survey of household budgets of the Central Statistical Office [3], in the classification consistent with COICOP / HBS1, 12 main groups of consumer spending are distinguished [5], including expenditure on transport and communication. Expenditure on transport includes: the purchase of means of transport (new and used passenger cars, two-wheeled motor vehicles, bicycles, vehicles drawn by animals), an operation of private transport means and transport services. The monthly household spent on transport on average 89.24 PLN per person, whereas over $73 \%$ of this amount was spent on the operation of private means of transport (Table 1).

Tab. 1. The level and structure of average expenditure on transport and communication in $50+$ households in 2014

\begin{tabular}{|c|c|c|}
\hline Specification & Expenses in PLN & Structure (\%) \\
\hline $\begin{array}{c}\text { Total transport } \\
\text { expenditure, including: }\end{array}$ & $\mathbf{8 9 , 2 3}$ & $\mathbf{1 0 0 , 0 0}$ \\
\hline means of transport & 8,32 & 9,33 \\
\hline $\begin{array}{c}\text { operation of private } \\
\text { transport }\end{array}$ & 65,32 & 73,20 \\
\hline transportation services & 15,59 & 17,47 \\
\hline $\begin{array}{c}\text { Total communication } \\
\text { expenditure, including: }\end{array}$ & $\mathbf{6 0 , 3 4}$ & $\mathbf{1 0 0 , 0 0}$ \\
\hline postal services & 0,48 & 0,79 \\
\hline $\begin{array}{c}\text { telecommunications } \\
\text { equipment }\end{array}$ & 0,80 & 1,34 \\
\hline
\end{tabular}


telecommunication services

59,06

97,87

Source: own calculations based on individual non-identifiable data provided by the Central Statistical Office.

In the entire period from Poland's accession to the European Union, a clear trend of the growth in the share of road transport in passenger transport is registered [5]. The category of communication concerns: postal services (sending letters, parcels, purchase of stamps and postcards, with the exception of those purchased for collection purposes); telecommunications equipment (purchase of telephones, radiotelephones, telefax telephones), telecommunications services (charges for telephone calls, internet services, telephone installations) and other telecommunications services (charges for calls from public machines, calls from hotels, restaurants, purchase of tokens and telephone cards). The average level of communication expenditure was 60.34 PLN per person, of which almost $98 \%$ related to telecommunications services.

Table 2 presents the structure of expenditure on transport and communication in households by socio-economic groups and households of people aged 50+. As shown in the table, expenditure related to transport was spent from $4.44 \%$ on pensioners' households to $10.82 \%$ of expenditure on farms of farmers. The share of these expenditures in 50+ farms was $6.87 \%$ and was higher than in pensioners and retirees. In the case of expenditure on communication, their share in total expenditure did not differ significantly in the analyzed groups and amounted to around $5 \%$.

Tab. 2. Share of expenditure on transport and communication in total expenditure in households by socio-economic groups and households of people aged 50+ in 2014 (in\%)

\begin{tabular}{|c|c|c|c|c|c|c|}
\hline \multirow{2}{*}{ Specification } & \multicolumn{6}{|c|}{ Households of } \\
\cline { 2 - 7 } & $\begin{array}{c}\text { employe } \\
\text { es }\end{array}$ & farmers & $\begin{array}{c}\text { self- } \\
\text { employe } \\
\text { d }\end{array}$ & retirees & $\begin{array}{c}\text { pensione } \\
\text { rs }\end{array}$ & $\begin{array}{c}\text { people } \\
\text { aged 50+ }\end{array}$ \\
\hline Transport & 10,63 & 10,82 & 10,22 & 5,77 & 4,44 & 6,87 \\
\hline Communication & 5,21 & 4,82 & 5,05 & 4,56 & 4,92 & 4,64 \\
\hline
\end{tabular}

Source: own calculations based on [1] and individual non-identifiable data provided by the Central Statistical Office.

In tab. 3, the results of the analysis of expenditure on transport and communication in various cross-sections are presented, all descriptive parameters were calculated using the number of people in the household. The average level of total expenditure is determined by the class of the place of residence, which means that as the number of inhabitants increases, the expenditure increases. Such a tendency can be noticed in the case of communication expenditure, which ranged from 88.27 PLN / person. in the largest cities up to 47.48 PLN per person. in the countryside, their share in total expenditure also decreased. Most of the transports were also issued by city dwellers. 500 thousand population, but their share in total expenditure was lower by 1.15 percentage points than the residents of the village. This is mainly due to commuting to work, schools, cultural and sports centers, and shopping malls. The average value of expenditure on transport and communication also depends on the type of biological family. In the case of both types of expenditure, a significant share of total expenditure for marriages with children and other dependents is noticeable. 
Tab. 3. Basic descriptive characteristics of the distribution of expenditure on transport and communication according to socio-economic characteristics and the place of residence of 50+ households

\begin{tabular}{|c|c|c|c|c|c|}
\hline Specification & $\begin{array}{l}\text { Average } \\
\text { total } \\
\text { expenses } \\
\text { (In } \\
\text { PLN) } \\
\text { (1) }\end{array}$ & $\begin{array}{l}\text { Average } \\
\text { transport } \\
\text { expenses } \\
\text { (in PLN) } \\
\text { (2) }\end{array}$ & $\begin{array}{l}\text { Average } \\
\text { expenses on } \\
\text { communication } \\
\text { (in PLN) (3) }\end{array}$ & $\begin{array}{l}\text { Share } \\
(2) /(1) \\
(\text { in } \%)\end{array}$ & $\begin{array}{l}\text { Share } \\
(3) /(1) \\
(\text { in } \%)\end{array}$ \\
\hline Total & 1299,62 & 89,24 & 60,34 & 6,87 & 4,64 \\
\hline \multicolumn{6}{|l|}{ Place of residence class } \\
\hline $\begin{array}{l}\text { City with over } 500 \text { thous. } \\
\text { residents }\end{array}$ & 1715,77 & 117,33 & 88,27 & 6,84 & 5,14 \\
\hline $\begin{array}{l}\text { City with 200-499 thous. } \\
\text { residents }\end{array}$ & 1477,92 & 82,37 & 78,05 & 5,57 & 5,28 \\
\hline $\begin{array}{l}\text { City with 100-199 thous. } \\
\text { residents }\end{array}$ & 1427,14 & 83,33 & 68,60 & 5,84 & 4,81 \\
\hline City with 20-99 thous.residents & 1364,40 & 86,69 & 64,31 & 6,35 & 4,71 \\
\hline City below 20 thous. residents & 1237,64 & 75,25 & 55,43 & 6,08 & 4,48 \\
\hline Village & 1119,80 & 89,43 & 47,48 & 7,99 & 4,24 \\
\hline \multicolumn{6}{|l|}{ Biological type of household } \\
\hline Marriage without children & 1402,94 & 113,71 & 61,05 & 8,11 & 4,35 \\
\hline $\begin{array}{l}\text { Marriage with one dependent } \\
\text { child }\end{array}$ & 1119,85 & 111,58 & 63,72 & 9,96 & 5,69 \\
\hline $\begin{array}{l}\text { Marriage with at least one } \\
\text { dependent child and other } \\
\text { people }\end{array}$ & 765,47 & 81,35 & 42,55 & 10,63 & 5,56 \\
\hline Single-person households & 1563,39 & 66,19 & 70,11 & 4,23 & 4,48 \\
\hline \multicolumn{6}{|c|}{ Subjective assessment of the material situation } \\
\hline Very good & 2090,16 & 203,02 & 88,67 & 9,71 & 4,24 \\
\hline Rather good & 1652,96 & 138,42 & 75,66 & 8,37 & 4,58 \\
\hline Average & 1227,81 & 79,62 & 58,35 & 6,48 & 4,75 \\
\hline Rather bad & 1004,18 & 44,12 & 47,25 & 4,39 & 4,71 \\
\hline Bad & 908,93 & 36,87 & 39,88 & 4,06 & 4,39 \\
\hline \multicolumn{6}{|c|}{ Education of the household head } \\
\hline At east junior high school & 980,94 & 37,02 & 37,33 & 3,77 & 3,81 \\
\hline Basic vocational & 1084,32 & 74,52 & 51,28 & 6,87 & 4,73 \\
\hline Secondary education & 1366,15 & 74,64 & 69,17 & 5,46 & 5,06 \\
\hline Secondary vocational & 1420,09 & 106,61 & 69,01 & 7,51 & 4,86 \\
\hline Higher & 2037,25 & 181,28 & 96,96 & 8,90 & 4,76 \\
\hline \multicolumn{6}{|l|}{ Age-class household head } \\
\hline $50-54$ & 1210,61 & 120,29 & 63,09 & 9,94 & 5,21 \\
\hline $55-59$ & 1298,13 & 110,00 & 64,28 & 8,47 & 4,95 \\
\hline $60-64$ & 1334,96 & 100,54 & 62,69 & 7,53 & 4,70 \\
\hline $65-69$ & 1381,98 & 83,07 & 62,11 & 6,01 & 4,49 \\
\hline 70 and more & 1289,76 & 47,74 & 52,82 & 3,70 & 4,10 \\
\hline
\end{tabular}

Source: own calculations based on individual non-identifiable data provided by the Central Statistical Office. 
The subjective assessment of the financial situation of the holding is also important for the average expenditure on transport and communication. As can be seen from table 3, a better assessment is accompanied by an increase in average expenditure. This is particularly evident in the case of transport expenditures, which on farms that assess their financial situation very well, are almost six times higher than on farms with a bad situation. Along with the improvement of the material situation, their share in total expenditure also grows. For expenditure on communications, despite the increase in their value along with a better material situation, the share in total expenditure does not show large discrepancies.

Table 3 also provides relevant information on the expenditure under analysis related to households due to the special characteristics of the head of the holding, i.e. its education and age. The higher education, the more households devote to both transport and communication, while significant differences in the share of these expenditures in total expenditure are noticeable only in the case of transport expenditures. Five age classes were adopted to analyze the evolution of spending due to the age of the head of the household. With the aging of the household head, both average transport and communication expenses as well as their share in total expenditure drop. Such a conclusion is not in doubt, as a social and professional activity of society diminishes with age.

\section{Econometric modeling of expenditure on transport and communication in 50+ households}

In this part of the article, a collection of 20607 households was analyzed, of which about $32 \%$ did not bear transport expenses, and $4 \%$ did not spend their resources on communication. In order to examine the impact of selected household features on the level of expenditure on transport and communication on 50+ households, a power-exponential model was used [8]:

$$
\begin{aligned}
& \ln W Y D A Z_{r i}=\alpha_{0 \mathrm{r}}+\alpha_{1 \mathrm{r}} \ln W Y D_{i}+\alpha_{2 \mathrm{r}} \operatorname{lnLOS}_{i}+\alpha_{3 \mathrm{r}} \ln W I E K_{i}+\sum_{k=2}^{6} \beta_{r k} M Z_{i k}+\gamma_{r} W w_{i}+ \\
& \sum_{s=2}^{4} \delta_{r s} O S_{i s}+\varepsilon_{r i},
\end{aligned}
$$

where:

$W Y D A Z_{r i}$ - average monthly expenditure on the group of goods or services per one person in the i-th household,

$W Y D_{i}$-average monthly total expenditure per person in the i-th household,

$L O S_{i}$ - number of people in the i-th household;

$W I E K_{i}$ - the age of the head of the i-th household;

$M Z_{i k}$ - zero-one variables identifying the class of the place of residence and taking the value 1 if the $\mathrm{i}$-th household belongs to the $\mathrm{k}$-th class of the place of residence: $\mathrm{k}=2$ for cities over 500 thousand residents, $\mathrm{k}=3$ for cities with a population of 200-499 thousand, $\mathrm{k}=4$ for cities with a population of 100-199 thousand, $\mathrm{k}=5$ for cities with a population of 20-99 thousand, $\mathrm{k}=6$ for cities below 20 thousand inhabitants, the basis of the comparison is the village;

$W w_{i}$ - zero-one variable taking the value 1 , if the head of the i-th household has a university degree, 0 - in the opposite case;

$O S_{\text {is }}$ - zero-one variables created due to subjective assessment of own financial situation of households and taking the value 1, if the i-th household belongs to the s-th group assessing their financial situation: $s=2$ - very good material situation, $s=3$ - the material situation is rather good, $\mathrm{s}=4$ - the material situation is rather bad, $\mathrm{s}=5$ - the material situation of evil, the basis of comparison is the average material situation.

$\alpha, \beta, \gamma, \delta$-structural parameters of the model,

$\varepsilon_{r i}$ - random component.

The estimated parameter $\alpha_{1}$ informs about the percentage of the average monthly change on transport (or communication), with the increase of the monthly total expenditure per 1 person 
by $1 \%$, assuming that the remaining variables are constant. The assessment of the $\alpha_{2}$ parameter is the elasticity of expenditure in relation to the number of people in the household and determines the effects of the scale of management depending on the size of the family. The estimated parameter $\alpha_{3}$ informs about changes in average monthly expenses when the age of the household head increases. On the other hand, the $\gamma$ parameters show differences in preferences related to the class of the place of residence, education of the head of the household and subjective assessment of the own financial situation of households. The final selection of explanatory variables to the model was made by stepwise regression. Estimates of the model parameters were made using the classical method of the smallest squares. The results are presented in tab. 4 and 5

Tab. 4. Assessment of the parameters of the exponent-exponential model of expenditure on transport in 50+ households

\begin{tabular}{|l|l|l|l|l|}
\hline Parameter & $\begin{array}{l}\text { Parameter } \\
\text { evaluation }\end{array}$ & Standard error & $\mathrm{t}(19060)$ & $p$ level \\
\hline$\alpha_{0 \mathrm{r}}$ & 0,5245 & 0,3027 & 1,7327 & 0,0832 \\
\hline$\alpha_{1 \mathrm{r}}$ & 1,1536 & 0,0196 & 58,8185 & 0,0000 \\
\hline$\alpha_{2 \mathrm{r}}$ & 0,2616 & 0,0210 & 12,4742 & 0,0000 \\
\hline$\alpha_{3 \mathrm{r}}$ & $-1,1090$ & 0,0609 & $-18,2229$ & 0,0000 \\
\hline$\gamma_{r}$ & 0,1436 & 0,0243 & 5,9024 & 0,0000 \\
\hline$\beta_{r 2}$ & $-0,2267$ & 0,0282 & $-8,0350$ & 0,0000 \\
\hline$\beta_{r 4}$ & $-0,3225$ & 0,0315 & $-10,2523$ & 0,0000 \\
\hline$\beta_{r 5}$ & $-0,2935$ & 0,0333 & $-8,8041$ & 0,0000 \\
\hline$\beta_{r 6}$ & $-0,2338$ & 0,0232 & $-10,0608$ & 0,0000 \\
\hline$\delta_{r 2}$ & 0,1022 & 0,0331 & 3,0865 & 0,0020 \\
\hline$\delta_{r 3}$ & 0,0884 & 0,0231 & 3,8221 & 0,0001 \\
\hline$\delta_{r 4}$ & $-0,1934$ & 0,0272 & $-7,1195$ & 0,0000 \\
\hline$\delta_{r 5}$ & $-0,2231$ & 0,0428 & $-5,2070$ & 0,0000 \\
\hline $\mathrm{R}=0,634 ; \mathrm{R}^{2}=0,402 ; \mathrm{F}=501,65 ; \mathrm{p}<0,0000$ & & \\
\hline
\end{tabular}

Source: own calculations based on individual non-identifiable data provided by the Central Statistical Office.

Tab. 5. Assessment of the parameters of the exponent-exponential model of spending on communication in 50+ households

\begin{tabular}{|l|l|l|l|l|}
\hline Parameter & $\begin{array}{l}\text { Parameter } \\
\text { evaluation }\end{array}$ & Standard error & $\mathrm{t}(19060)$ & $p$ level \\
\hline$\alpha_{0 \mathrm{r}}$ & 3,3867 & 0,1459 & 23,2190 & 0,0000 \\
\hline$\alpha_{1 \mathrm{r}}$ & 0,4843 & 0,0094 & 51,5899 & 0,0000 \\
\hline$\alpha_{2 \mathrm{r}}$ & $-0,1314$ & 0,0100 & $-13,1979$ & 0,0000 \\
\hline$\alpha_{3 \mathrm{r}}$ & $-0,6996$ & 0,0289 & $-24,2093$ & 0,0000 \\
\hline$\gamma_{r}$ & 0,1872 & 0,0128 & 14,6632 & 0,0000 \\
\hline$\beta_{r 2}$ & 0,2899 & 0,0140 & 20,6510 & 0,0000 \\
\hline$\beta_{r 4}$ & 0,2609 & 0,0150 & 17,4070 & 0,0000 \\
\hline$\beta_{r 5}$ & 0,1641 & 0,0163 & 10,0644 & 0,0000 \\
\hline$\beta_{r 6}$ & 0,1354 & 0,0112 & 12,0982 & 0,0000 \\
\hline$\delta_{r 2}$ & 0,0595 & 0,0175 & 3,4113 & 0,0006 \\
\hline$\delta_{r 3}$ & 0,0836 & 0,0119 & 6,9967 & 0,0000 \\
\hline$\delta_{r 4}$ & $-0,1189$ & 0,0124 & $-9,5543$ & 0,0000 \\
\hline$\delta_{r 5}$ & $-0,2826$ & 0,0188 & $-15,0001$ & 0,0000 \\
\hline
\end{tabular}


$\mathrm{R}=0,684 ; \mathrm{R}^{2}=0,469 ; \mathrm{F}=798,55 ; \mathrm{p}<0,0000$

Source: own calculations based on individual non-identifiable data provided by the Central Statistical Office.

As the values of parameter assessments on the variability of transport expenditures (expressed in PLN per person) indicate, the level of total expenditure has the highest impact (Table 4). The increase in total expenditure by $1 \%$ raises the level of transport expenditures by an average of $1.154 \%$, assuming the stability of other variables. Next, the age of the head of the household negatively influences the level of discussed expenses. The increase in the number of people on the farm causes an increase in spending on transport, which is the expression of the so-called scale of management. The fact that the head of the household had a higher education resulted in an increase in expenses as compared to the farms in which the head had at most secondary education. The negative effect of the zero-one variable concerning living in cities of various sizes with regard to living in the countryside is negative.

There were also significant differences in the level of expenditures on the transport of households assessing their financial situation as average (reference basis) and expenditures of households with a rather bad or bad and very good and good situation. Households with a bad and rather bad financial situation incur expenditures lower than the farms constituting the reference base on average by approximately $20.0 \%$, i.e. $\left(e^{-0,2231}-1\right) \cdot 100 \%=20 \%$ oraz $17,6 \%$, tj. $\left(e^{-0,1934}-1\right) \cdot 100 \%=-17,6 \%$. In contrast, households with a very good and good situation spend on transport on average more by $10.8 \%$ and $9.2 \%$.

Analyzing the power-exponential model of spending on communication in $50+$ households (Table 5), a similar effect of the majority of explanatory variables can be observed, as in the case of transport expenditures. The only difference concerns the zero-one variable describing the place of residence, which positively affects the expenses related to communication. It turns out that with the increase in the number of residents in cities, expenses increase from $15 \%$ to $34 \%$.

The coefficients of determination of the estimated models of more than $40 \%$ mean that less than half of the overall observed variability of the explained variables has been explained by the models. Considering the fact that the subject of the study is a single household and we have to deal with a large dose of individualism in making decisions about expenses in a particular month, this coefficient can be considered satisfactory.

\section{Conclusions}

The analysis carried out in the article leads to the following conclusions:

1. The average 50+ household allocates approx. $6.87 \%$ of total expenditure on transport and $4.64 \%$ of communication expenditure.

2. The average level of communication expenditure is a function of the size of the city. With the increase in the urbanization of the city to which the household belongs, expenses are increasing. Transport expenses are slightly different. Despite the fact that the average population per capita is spent by the residents of the largest cities, the share of these expenditures in total expenditure was the highest for farms living in the countryside.

3. Taking into account the biological type of the family in 50+ households, a higher share of both types of expenditure analyzed in total expenditure for marriages with at least one dependent child and other persons can be noticed.

4. Subjective assessment of the material situation of the farm affects primarily, expenditure on transport, the better the situation, the higher the level and the share of these expenses. In the case of expenditure on communication, their share in total expenditure is not dependent on the material situation. 
5. Education and the age of the head of the household are of significant importance for the analyzed expenditure. Together with the increase in the education level of the head of the $50+$ household, the share of especially transport expenditures in total expenditure increases significantly. The age of the household's head has a different influence, both the level and the share of the analyzed expenditure have been declining over the years

6. The power-exponential model used in the article turned out to be a useful tool in research on spending on transport and communication of 50+ households. The largest positive impact on the expenditure analyzed was the level of total expenditure per person. It was also important to diversify the preferences of spending on transport and communication depending on the number of people in the family, the class of the place of residence, membership in the socio-economic group and subjective assessment of the material situation of the farm. In addition, it turned out that the expenditure studied also depends on the characteristics of the head of the household: they decrease with age, and the higher the education

\section{Source materials}

[1] Bąk I. Statystyczna analiza aktywności turystycznej seniorów w Polsce. Wydawnictwo Uczelniane Zachodniopomorskiego Uniwersytetu Technologicznego w Szczecinie, Szczecin 2013, s. 183.

[2] Bombol M., Słaby T. Konsument 55+ wyzwaniem dla rynku. Oficyna Wydawnicza SGH w Warszawie, Warszawa 2011, s. 8, 140-141.

[3] Budżety gospodarstw domowych w 2014 roku, GUS, Warszawa 2015.

[4] Frątczak E., Sobieszak A. Sytuacja demograficzno-społeczna osób starszych. W: Seniorzy w społeczeństwie polskim. GUS, Warszawa 1999, s. 13.

[5] Gaca S., Transport drogowy - rola i wybrane aspekty rozwoju infrastruktury, Przegląd Komunikacyjny, nr 08/2017, s. 18.

[6] Metodologia badania budżetów gospodarstw domowych. Zakład Wydawnictw Statystycznych, GUS, Warszawa 2011.

[7] Migdal-Najman K., Szreder M. Nowe trendy demograficzne a zmiany konsumpcji w Polsce. Marketing i Rynek nr 11, Warszawa 2013, s. 2.

[8] Podolec B. Wybrane aspekty analizy warunków życia ludności w Polsce. Metody ilościowe w badaniach empirycznych. Krakowska Akademia im. Andrzeja Frycza Modrzewskiego, Kraków 2014, 51-71.

[9] Zalega T. Gospodarstwo domowe jako podmiot konsumpcji. Studia i Materiały Wydziału Zarządzania Uniwersytetu Warszawskiego nr 1, Warszawa 2007, s. 7. 